\title{
ВИКОРИСТАННЯ НЕПРЯМИХ ОЗНАК ТА ІНДЕКСІВ У СЕЛЕКЦЇ̈ КВАСОЛІ ЗВИЧАЙНӦ̈ НА СТАБІЛЬНУ ПРОДУКТИВНІСТЬ
}

О. Т. Дупляк, В. А. Бовгира

Національний університет біоресурсів і природокористування України

Наведено результати вивчення продуктивності та 11 індексних ознак у колекційних зразків квасолі звичайної різного еколого-географічного походження. Для подальшої практичної селекції для умов Лісостепу рекомендовано 11 джерел комплексу господарсько важливих ознак та п'ять стабільної продуктивності. В групах детермінантних та індетермінантних сортозразків на рівні міжсортових фенотипових коефіцієнтів кореляції $\mathrm{r} \geq 0,5$ виявлено плеяди продуктивності (продуктивність, НI, Mx, AI, I, ГІ з ознакою-індикатором НI) та збирального індекса (HI, продуктивність, Mic, AI, SI). Для підвищення достовірності оцінок селекційних ліній квасолі звичайної за продуктивністю на ранніх етапах селекції рекомендовано використовувати як вторинні ознаки індекси НІ та ГІ.

Квасоля звичайна, колекція, ознака, продуктивність, стабільність, індекс, корелячія

Квасоля є традиційною для України продовольчою культурою. Незважаючи на високу іiі поживну цінність, площі, як і урожайність, продовжують залишатись незначними (в 2010 р. відповідно 22,6 тис. га та 1,28 т/га). В результаті, країна виробляє менше $1 \%$ світового валового збоpy ( в 2010 p. 28,8 тис. тонн), далеко не задовольняючи попит на внутрішньому та експортному ринках.

Зареєстровані в Україні на 2012 рік сорти зернової квасолі $(14$, із них два іноземного походження) відзначаються високою чутливістю до факторів середовища, особливо температурного режиму та умов вологозабезпечення. В Лісостепу України занадто високі температури повітря (вище $30^{\circ} \mathrm{C}$ ) та відсутність опадів протягом тривалого часу в літній період спостерігаються все частіше. І це $\epsilon$ причиною значних річних коливань урожайності культури, які перевищують сортові відмінності в два і більше разів. Створення сортів інтенсивного типу, пристосованих до мінливих умов зони Лісостепу України, можливе з використанням специфічних підходів до розроблення методів селекції цієї культури. В останній час у селекційних технологіях багатьох сільськогосподарських культур (гороху, сої, кормових бобів, нуту, озимої пшениці) все ширше використовуються селекційні індекси $[1,2]$, що

(C) О. Т. Дупляк, В. А. Бовгира. 2012.

ISSN 0582-5075. Селекція і насінництво. 2012. Випуск 102. 
забезпечує більш достовірну оцінку продуктивності порівняно 3 прямим оцінюванням рослин та дозволяє реально розгрузити селекційний процес. Питання покращення прогнозування урожайності потомків за вторинними ознаками (індексами) у квасолі практично не вивчалось.

Дослідження проводились протягом 2009-2010 років на полях селекційно-насінницької сівозміни кафедри селекції і генетики НУБіП України (с. Пшеничне Васильківського району Київської області). Грунти чорноземи типові з вмістом гумусу в орному шарі $4,4 \%$, $\mathrm{pH}-7,1$, грунтові води залягають на глибині 4 м. Кліматичні умови відповідають зоні помірного зволоження з тенденцією в останні роки до зменшення суми опадів та підвищення середньодобових температур в окремі місяці.

Об'єктом досліджень були 30 сортозразків квасолі звичайної (Phaseolus vulgaris L.) різного еколого-географічного походження (57 \% 3 країн далекого і 20 \% - близького зарубіжжя, 23 \% вітчизняних).

Сівбу колекційного розсадника проводили вручну в другій декаді травня. Спосіб сівби - широкорядний (через 45 см); норма висіву - 350 тис. схожих насінин на 1 га. Площа ділянки - 1,35 (в 2009 р.) та 1,8 (2010 р.) кв. м. Стандарти (Первомайська та Мавка) висівались через кожних 10 номерів. Агротехніка досліду - загальноприйнята для зони.

Предмет досліджень -продуктивність та 11 індексних ознак, зокрема: кількість бобів на один продуктивний вузол (КБПВ), виповненість бобів (ВБ), збиральний індекс (відношення маси насіння з рослини до маси рослини - НI), індекс мікророзподілу ( відношення маси насіння до маси створок - Міс), «мексиканський» індекс (відношення маси насіння з рослини до довжини стебла - Мх), довжина міжвузля (відношення довжини стебла до загальної кількості вузлів - ДМ), довжина міжвузля до першого боба ( відношення висоти до першого боба до кількості вузлів до першого боба ДМ1Б), індекс інтенсивності (відношення маси стебла до його довжини $\mathrm{SI})$, індекс атракції (відношення маси бобів з рослини до маси стебла - AI), відношення кількості продуктивних вузлів на рослині до загальної кількості вузлів (I), відношення маси насіння з рослини до довжини міжвузля (ГІ).

Коефіцієнт стабільності продуктивності визначали за формулою: $\mathrm{St}=$ $\left(\mathrm{X}_{\mathrm{lim}}-\mathrm{C}_{\mathrm{opt}}\right) / 100$, де $\mathrm{X}_{\mathrm{lim}}-$ середня величина ознаки за несприятливих умов; $\mathrm{C}_{\text {opt }}$ - середня величина ознаки за оптимальних умов.

В роботі керувались методиками різних авторів $[3,4,5]$; статистичну обробку експериментальних даних проведено за допомогою пакету ліцензійних програм Microsoft Excel, Statistica.

За результатами досліджень в обидва роки вищою середньою продуктивністю характеризувались сортозразки з необмеженим характером росту стебла (табл. 1). В 2009 р. вони перевищили детермінантні форми на 102,8, в 2010 р. - на $26,5 \%$.

Отримані експериментальні дані, окрім залежності продуктивності рослин від генотипу сорту, показують значний вплив умов середовища на рівень прояву ознаки. 
Таблиця 1

Характеристика колекції квасолі за продуктивністю та індексними ознаками

\begin{tabular}{|c|c|c|c|c|c|c|c|c|}
\hline \multicolumn{9}{|c|}{ (2009-2010 pp.) } \\
\hline \multirow{2}{*}{ Ознаки } & \multicolumn{2}{|c|}{2009 p. } & \multicolumn{2}{|c|}{$2010 \mathrm{p}}$. & \multicolumn{2}{|c|}{ St, \% } & \multicolumn{2}{|c|}{$\mathrm{V}, \%$} \\
\hline & $\lim$ & Cep. & $\lim$ & Cep. & $\lim$ & Cep. & $\lim$ & Cep. \\
\hline \multicolumn{9}{|c|}{ Детермінантні } \\
\hline Продуктивність & $\begin{array}{l}2,4- \\
11.6\end{array}$ & 7,3 & $\begin{array}{l}2,2- \\
8,2\end{array}$ & 4,9 & $\begin{array}{c}31,0- \\
97,6\end{array}$ & 66,0 & $\begin{array}{l}11,9- \\
31,0\end{array}$ & 21,6 \\
\hline Індексні & $\begin{array}{c}0,10- \\
4,65\end{array}$ & - & $\begin{array}{c}0,07- \\
4,92\end{array}$ & - & $\begin{array}{c}64,7- \\
94,5\end{array}$ & 82,0 & $\begin{array}{c}11,2- \\
48,7\end{array}$ & 22,4 \\
\hline \multicolumn{9}{|c|}{ Індетермінантні } \\
\hline Продуктивність & $\begin{array}{l}7,8- \\
26,5\end{array}$ & 14,8 & $\begin{array}{l}3,7- \\
13,3\end{array}$ & 6,2 & $\begin{array}{c}20,7- \\
91,4\end{array}$ & 47,0 & $\begin{array}{l}15,2- \\
39,8\end{array}$ & 25,3 \\
\hline Індексні & $\begin{array}{c}0,10- \\
4,72\end{array}$ & - & $\begin{array}{c}0,05- \\
4,35\end{array}$ & - & $\begin{array}{c}37,5- \\
99,7\end{array}$ & 72,2 & $\begin{array}{c}12,2- \\
49,6\end{array}$ & 23,4 \\
\hline
\end{tabular}

Причому модифікаційні відмінності в ряді випадків істотно перевищили сортові, що свідчить про низькі адаптивні властивості переважної частини колекції. В зв'язку зі змінами клімату в останні роки селекцію сортів квасолі в умовах Лісостепу доцільно спрямувати на створення сортів з потужною кореневою системою та пониженою інтенсивністю транспірації.

За результатами досліджень для практичної селекції в умовах Лісостепу України виділено і рекомендовано наступні джерела:

- комплексу господарсько-цінних ознак (високої врожайності, продуктивності і складових іiі елементів): з детермінантним типом росту - Black marvil (Ukr 008:02651, Німеччина), Пловдів 19 (Ud0303008, Румунія), Gama (Ud0300856, Словаччина), з верхівкою, що завивається, - Місцевий (Ud0301025, Афганістан), Great Northern (Ud0300565, США), Ukr 008:02657 (Україна), Tetenyi kozep (Ukr 008:01992, Угорщина), Докучаєвська (Ukr 008:02641, Україна), Izsaki (Ud0302397, Угорщина);

- стабільності: детермінантні - Black marvil (Ukr 008:02651, Німеччина), Valja (Ukr 008:01994, Німеччина), Bela nad cirochon (Ud0302721, Угорщина), індетермінантні (з верхівкою, що завивається) - Докучаєвська (Ukr 008:02641, Україна), Мавка (Україна).

Індексні ознаки, за даними табл. 1, значною мірою визначаються генотипом сорту і $\epsilon$, порівняно з продуктивністю, більш стабільними. Найтісніший зв'язок (на рівні $\mathrm{r}=0,90-0,95$ ) в обидва роки досліджень в обох групах сортозразків спостерігався з індексом ГІ, який визначається відношенням маси насіння з рослини до довжини міжвузля. Досить тісний зв'язок виявлено також між продуктивністю та «мексиканським індексом» Мх: в детермінантних зразків $\mathrm{r}=0,85-0,91$, в індетермінантних $-0,93-0,95$. Останні характеризуються меншим розмахом варіювання ознаки $(\mathrm{r}=0,63-0,90)$; в детермінантів $\mathrm{r}=0,41-1,00$ (за винятком Конкурент СКВ № 230/9). В обох групах зразків середній-тісний зв'язок спостерігався між продуктивністю та збира- 
льним індексом, індексом атракції. Амплітуда значень ознаки тут значно ширша, особливо в індетермінантних форм.

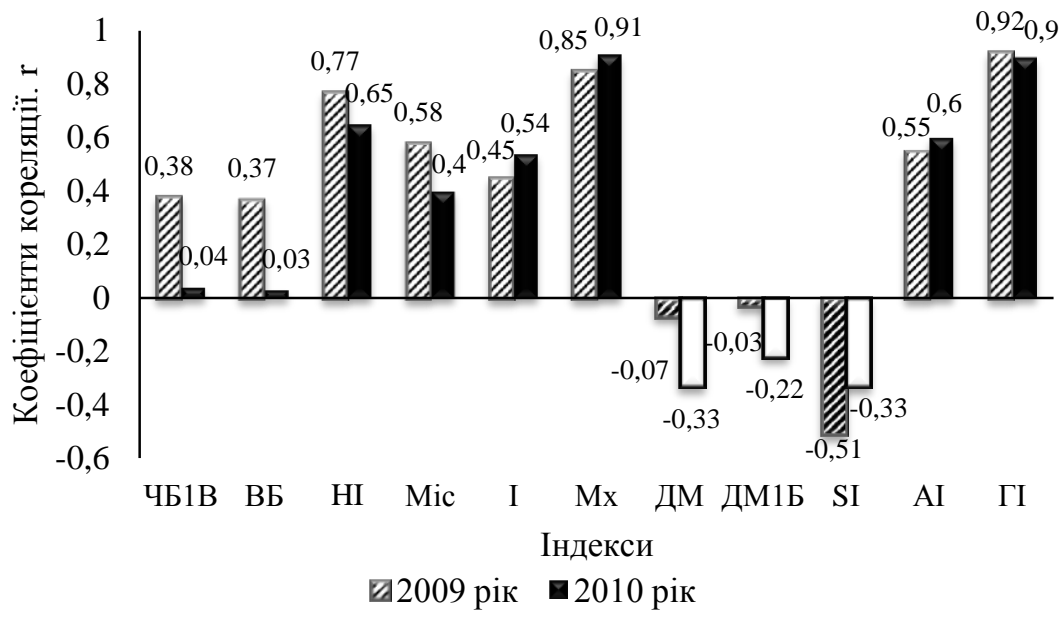

Рис 1. Кореляції між продуктивністю та вторинними ознаками у детермінантних сортозразків квасолі звичайної (2009-2010рр.)

На рівні міжсортових фенотипових коефіцієнтів кореляції $\mathrm{r} \geq 0,5$ в обох групах сортозразків чітко прослідковується плеяда продуктивності: продуктивність, НI, Мх, АI, I, ГI [6]. Ознакою-індикатором є збиральний індекс (НI); дещо менший «кореляційний шлях» в індекса ГІ.

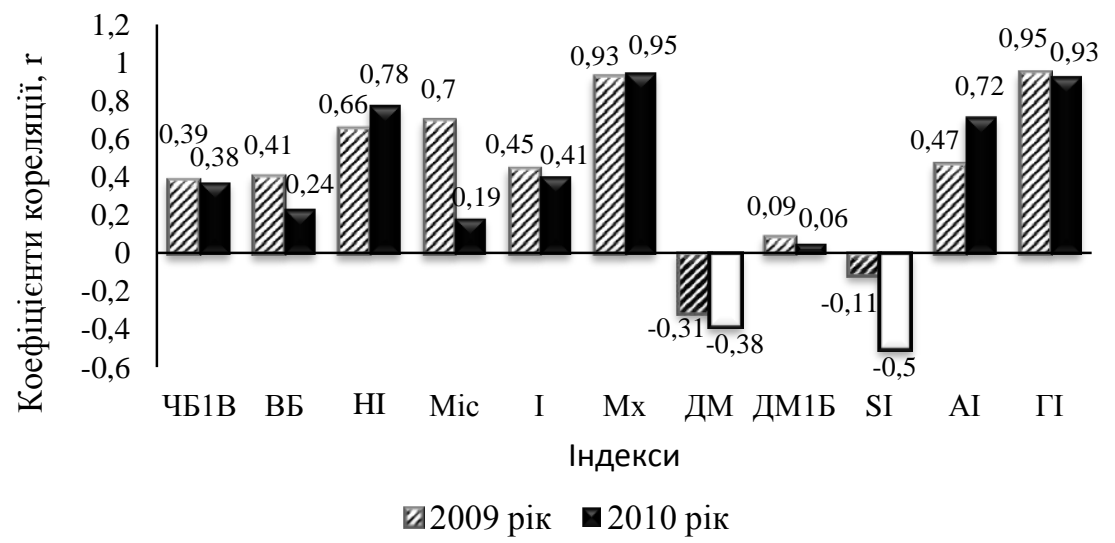

Рис.2. Кореляції між продуктивністю та індексними ознаками в індетермінантних сортозразків квасолі звичайної (2009-2010рр.) 
Щодо взаємозв'язків індексних ознак, то збиральний індекс показав тісну або середню міжсортову фенотипову кореляцію в групах інде- та детермінантних форм з індексами мікророзподілу та атракції, що вказує на їх основний внесок у продуктивність. Рослини з більшою кількістю бобів та інтенсивнішим відтоком пластичних речовин від асимілюючої їх частини до насіння, що формується, в кінцевому результаті забезпечать вищу продуктивність. За даними А. В. Дьякова та В. А. Драгавцева [7], В. Н. Тищенко, Н. М. Чекалина [2], АI та Міс контролюються незалежними генетичними системами. Це робить можливим об'єднання в одному генотипі шляхом гібридизації та добору високих показників за обома індексами. Середній та сильний негативний зв'язок виявлено між індексом інтенсивності SI, який характеризує властивість рослини формувати вегетативну масу, та збиральним індексом, індексом атракції. На рівні міжсортових фенотипових коефіцієнтів кореляції $\mathrm{r} \geq 0,5$ в обох групах виявлено плеяду збирального індекса: НI, продуктивність, Mic, AI, SI.

Висновки. 1. Результати вивчення колекції квасолі звичайної показали перевагу індетермінантних сортозразків над детермінантними за продуктивністю; виділено і рекомендовано для подальшої практичної селекції 11 джерел комплексу господарсько важливих ознак та п'ять стабільної продуктивності.

2. Дослідження особливостей прояву продуктивності та 11 індексних ознак у колекційних зразків квасолі звичайної показали їх залежність від генотипу сорту та умов середовища; порівняно з продуктивністю, більшість індексних ознак характеризуються вищою стабільністю. На рівні міжсортових фенотипових коефіцієнтів кореляції $r \geq 0,5$ в групах детермінантних та індетермінантних сортозразків виявлено плеяди продуктивності (продуктивність, НI, Мх, АI, I, ГІ з ознакою-індикатором НI) та збирального індекса (НI, продуктивність, Mic, AI, SI).

3. Для підвищення достовірності оцінок селекційних ліній квасолі звичайної за продуктивністю на ранніх етапах селекції доцільно використовувати як вторинні ознаки індекси НІ та ГІ.

\section{Список використаних джерел}

1. Тищенко В. Н. Характеристика селекционных индексов у линий озимой пшеницы по коэффициентам детерминации, вариации и генетическим корреляциям с продуктивностью / В. Н. Тищенко, Н. М.Чекалин. // Вісник Полтавської державної аграрної академії. - Полтава. - 2005.-№1. C. 10-16.

2. Тищенко В. Н. Генетические основы адаптивной селекции озимой пшеницы в зоне Лесостепи / В. Н. Тищенко, Н. М.Чекалин. - Полтава, 2005. $271 \mathrm{c}$.

3. Доспехов Б. А. Методика полевого опыта /Б. А. Доспехов-М., 1979. $423 \mathrm{c}$. 
4. Методические указания по изучению коллекции зернобобових культур. Ленинград, 1975.-6 с.

5. Рокицкий П. Ф. Введение в статистическую генетику / П. Ф. Рокицкий. Минск, 1974. - $446 \mathrm{c.}$

6. Терентьев П. В. Практикум по биометрии / П. В. Терентьев, Н .С. Ростова. - Л.: Изд-во Ленинград. ун-та, 1977. - 152 с.

7. Дьяков А. В. Конкурентноспособность растений в связи с селекцией. Сообщение 1. Надежность оценки генотипов по фенотипам и способ ее повышения / А. В. Дьяков, В. А. Драгавцев // Генетика. - 1975. - №5.- С. 11-22.

Приведены результаты изучения продуктивности и 11 индексных признаков коллекции фасоли обыкновенной разного экологогеографического происхождения в условиях Лесостепи Украины. Выделены и рекомендованы для практической селекции 11 источников комплекса хозяйственно-ценных признаков и пять стабильной продуктивности. В группах детерминантных и индетерминантных сортообразцов на уровне межсортовых фенотипических корреляций $r \geq 0,5$ выявлены плеяды продуктивности (продуктивность, НI, Mx, AI, I, ГІ с признаком-индикатором НI) и уборочного индекса (HI, продуктивность, Mic, AI, SI). Для повышения достоверности оценок селекционных линий на ранних этапах селекции как вторичные признаки рекомендовано использовать НІ та ГІ.

The article presents the results of the studies of the productivity and 11 index characteristics of garden bean collection of different ecological-geographical origin under the conditions of forest-steppe of Ukraine. 11 sources of the complex of economically valuable characteristics and 5 stable productivity sources are defined and recommended for practical selection. The productivity pleiads (productivity, HI, Mx, AI, I, ГI with the $\mathrm{HI}$ detector-characteristics) and harvest index (HI, productivity, Mic, AI, SI) are defined in the groups of determinantal and indeterminantal varieties at the level of intervarietal phenotypic correlations $r \geq 0,5$. HI and $\Gamma I$ are recommended to use for the increase of estimation reliability of the breeding lines at the early breeding stages as the secondary characteristics. 